\title{
Cognitive Dysfunction, Depression and Anxiety in a Cohort of Systemic Lupus Erythematosus Patients
}

\author{
ANDREEA LILI BARBULESCU ${ }^{2 *}$, RALUCA-ELENA SANDU2, MIHAI VIRGIL BOLDEANU³, FLORENTIN ANANU VREJU4, \\ RADU ALEXANDRU MIHAILOVICI ${ }^{5}$, LIDIA BOLDEANU ${ }^{6}$, HORATIU VALERIU POPOVICIU', RAZVAN ADRIAN IONESCU, \\ BOGDAN CATALIN ${ }^{9}$, ANDREEA CRISTINA STOIAN ${ }^{10}$, OANA ANDREEA FLORESCU ${ }^{11}$, CARMEN VALERIA ALBU ${ }^{12}$ \\ IUniversity of Medicine and Pharmacy of Craiova, Pharmacology Department, 2 Petru Rares Str., 200349 Craiova, Romania \\ 2University of Medicine and Pharmacy of Craiova, Biochemistry Department, 2 Petru Rares Str., 200349 Craiova, Romania \\ 3University of Medicine and Pharmacy of Craiova, Immunology Department, 2 Petru Rares Str., 200349 Craiova, Romania \\ ${ }^{4}$ University of Medicine and Pharmacy of Craiova, Rheumatology Department, 2 Petru Rares Str., 200349 Craiova, Romania \\ EUniversity of Medicine and Pharmacy of Craiova, Cardiology Department, 2 Petru Rares Str., 200349 Craiova, Romania \\ UUniversity of Medicine and Pharmacy of Craiova, Microbiology Department, 2 Petru Rares Str., 200349 Craiova, Romania \\ University of Medicine, Pharmacy, Science and Technology of Targu Mures,Department of Rheumatology, BFK and Medical \\ Rehabilitation, 38 Gheorghe Marinescu Str., 540139 Targu Mures, Romania \\ ${ }^{8}$ Carol Davila University of Medicine and Pharmacy Bucuresti, 3d Internal Medicine Department, 37 Dionisie Lupu Str., 020021 \\ Bucharest, Romania \\ 'University of Medicine and Pharmacy of Craiova, Physiology Department, 2 Petru Rares Str., 200349 Craiova, Romania \\ 10University of Medicine and Pharmacy of Craiova, Infectious disease Department, 2 Petru Rares Str., 200349 Craiova, Romania \\ ${ }^{11}$ University of Medicine and Pharmacy of Craiova, PhD student, Radiology and Imaging Department, 2 Petru Rares Str., 200349 \\ Craiova, Romania \\ ${ }^{12}$ University of Medicine and Pharmacy of Craiova, Neurology Department, 2 Petru Rares Str., 200349 Craiova, Romania
}

\begin{abstract}
SLE is the prototype of connective tissue diseases that can present the complete spectrum of neurologic and psychiatric disorders, cognitive dysfunction, depression and anxiety being more prevalent compared to general population, with an inputon patients' prognosis and quality of life. In this study we aimed to determine the presence of cognitive dysfunction, anxiety and depression in a cohort of SLE patients, and their relationship to disease activty and quality of life. We determined the presence of these neuropsychyatric manifestations in signfficant percentages, directly correlated to disease activity and with an impact of quality of life. Our results lead to its extension, with multicentric contribution, and underline the necessity and benefit of a careful and periodical neuropsychiatric examination, in order to recognize the clinical patterns in earlystages, apply the proper therapeutic measures, quantify the future damage and improve the outcome of these patients.
\end{abstract}

Keywords: systemic lupus erythematosus, cognitive dysfunction, depression, anxiety, disease activity, life quality.

Systemic lupus erythematosus (SLE) is a complex connective tissue disease, characterized by multisystem involvement, and although any of the autoimmune, inflammatory disease can determine neuroinflammation, it represents their prototype, being the tipical pathology that can produce neurological and psychyatric disorders [1-11]. Compared to other clinical patterns, their primary etiologic diagnosis is not so very easily to be established despite the availablity of many imagistic techniques [2, 12-15]. The clinical spectrum of neuropsychyatric SLE is complex, includes 19 entities, focal or diffuse, with variable prevalences [16], and from those, cognitive dysfunction, depression and anxiety are relatively often observed, with an important input on patients prognosis and life quality. As noticed in any autoimmune disease, imaging methods, along with immunologic studies, enable an early diagnosis and individualized therapeutic measures [1, 17-25].

\section{Experimental part}

The aim of the study was to determine the presence of cognitive dysfunction, anxiety and depression in a cohort of SLE patients, and their relationship to disease activty and quality of life.

\section{Matherial and methods \\ We performed a longitudinal, prospective study, which included a cohort of 22 patients, diagnosed with SLE,}

according to the ACR/SCLICC 2012 revised criteria [25], in the Department of Rheumatology, Emergency County Hospital of Craiova, Romania. The control group included 18 sex and age-matched subjects, without acute or chronic inflammatory diseases, history of connective tissue, other autoimmune diseases or neuropsychyatric pathology.

The study was performed in accordance with the Declaration of Helsinki and approved by the Ethics Committee of the University of Medicine and Pharmacy of Craiova. All patients provided their written informed consent, after receiving a standard form which mentioned that the results would be used for research purposes.

Patients evaluation included anamnestic data, clinical examination, laboratory tests and imagistic methods. Disease activity was assessed using Systemic Lupus Erythematosus Disease Activity Index (SLEDAI) [26], that ranges from 0 to 105 , and defines remission when is 0 , low activity 1-5, moderate activity 6-11, high disease activity 11-19 and very high disease activity over 20; a persistent SLEDAI over 3 defines a chronic activity [27].

Cognitive dysfunction, depression and anxiety were evaluated by the same examiner, blinded by clinical and labortory date. In order to assess the presence of cognitive dysfunction we used scale Montreal Cognitive Assessment scale (MoCA), that is relatively easy to be performed and evaluates five cognitive domains (attention, executive function, memory, visuospatial function and language). The 
MoCA assesses several cognitive domains: visuospatial functions copy of cube ( 1 point), clock drawing ( 3 points); naming 3 pictures ( 3 points); memory learning of 5 words - delayed recall 5 words (5points); attention, concentration, and working memory are evaluated using a sustained attention task (target detection using tapping; 1 point), a serial subtraction task (3 points), and digits forw ard and backward (1 point each); language repetition of 2 sentences ( 2 points); abstract thinking similarities ( 2 points); abstractthinking similarities ( 2 points); orientation 6 tasks ( 6 points). An MoCA score of less than 26 points was defined as cognitive dysfunction [28]. Depression was evaluated using HAM-D (Hamilton Depression Scale); a score under 7 points defines normal, 8-13 mild depresssion, 14-18 moderate, 19-22 severe and over 23 very severe depresion [29]. We assessed anxiety by using HAM-A (Hamiltopn Anxiety Rating Scale), with a total score range of 0-56, where $<17$ indicates mild severity, 18-24 mild to moderate and 25-30 moderate to severe [30].

Life quality was estimated using short form survey (SF36) and Systemic lupus erythematosus-specific Quality of Life questionnaire (SLEQol). SF-36 form is an indicator of overall health status, has eight scaled scores (energy, physical functioning, general health, pain, role limitation due to emotional problems, role limitation due to physical problems, emotional well-being and social functioning), each of them ranging from 0 to 100; lower scores correspond to high disability, high scores to less disablity [31, 32]. SLEQol quantifies six domains, including physiscal functioning ( 6 items), activities ( 9 items), symptoms (8items), treatment (4 items), mood (4 items) and selfimage ( 9 items), with a 7 points response scale. The scores range from 40 to 280, with higher values corresponding to worse quality of life [32].

Statistical analysis was performed using GraphPad Prism 5.5. Results are presented as mean $\pm S D$ and data were analyzed using t-test and One-way ANOVA for comparing groups, and Pearson/Spearman's coefficient for evaluating correlations. We considered a level of $p<0.05$ statistically significant.

\section{Results and disscusions}

We included 22 consecutive patients, 19 women and 3 men, with a mean age of $43.41+11.04$ years and a mean disease duration of $9.04+5.89$ years. The main characteristics of the study group are presented in table 1.

Table 1

BASELINE CHARACTERISTICS OF SLE PATIENTS

\begin{tabular}{|l|l|}
\hline Characteristics & $43.41 \pm 11.04$ \\
\hline Age (years) & $19(86.36)$ \\
\hline Sex (women) & $9.3 \pm 4.3$ \\
\hline Disease duration (years) & $11.01 \pm 4.12$ \\
\hline Education level (years) & $84.65 \pm 1116.7$ \\
\hline Anti-dsDNA (UI/ml) & $5.68 \pm 4.52$ \\
\hline Anti-Ro (UI/ml) & $21.77 \pm 17.42$ \\
\hline ACL IgG (GPL/ml) & $25.37 \pm 19.91$ \\
\hline ACL IgM (GPL/ml) & $83.93 \pm 21.98$ \\
\hline C3 (mg/dl) & $9.94 .0 \pm 6.82$ \\
\hline C4 (mg/dl) & $12(54.54)$ \\
\hline Immunosupressive treatment (n; $\%)$ & $14(63.63)$ \\
\hline GC (n; $\%$ ) & $3.88 \pm 4.81$ \\
\hline GC (mg) & $7.59 \pm 3.68$ \\
\hline SLEDAI & $71.14 \pm 30.68$ \\
\hline SLEQol & \\
\hline The results are presented as mean+stand
\end{tabular}

The results are presented as mean \pm standard deviation

or percentages $(\mathrm{n} \%)$.
Scoring disease activity, we recokned a mean SLEDAI of 7.59+3.68 ( $\min 3, \max 20$ ) (table1); most of the patients (14; $66.63 \%$ ) had a moderate disease activity, 36.36\% (8 patients) had a low disease activity, 1 patient a SLEDAI corresponding to an intense activity and 1 patient had a severe disease activity.

Cognitive dysfunction was diagnosed in a percentage of 55.54 of SLE patients (12), statistically significant different ( $p=0.001$ ) compared to control group (22.22\%; 4 patients), and involved mostly orientation and attention (figure 1a). The mean score calculated using MoCA was 25.05+2.29 ( $\min 20$; max 28) (fig. 1b), for most of the patients registering a score corresponding to a mild cognitive dysfunction.



Fig. 1a. Cognitive dysfunction in patients/ controls; b. MoCA score for SLE/controls.
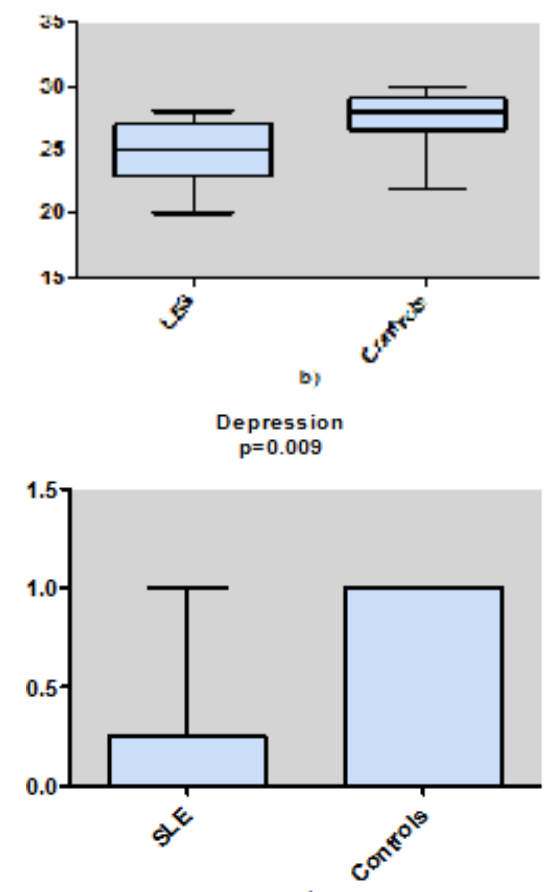

a)

Fig. 2. The presence of a) depression and b) anxiety in SLE cohort/controls.

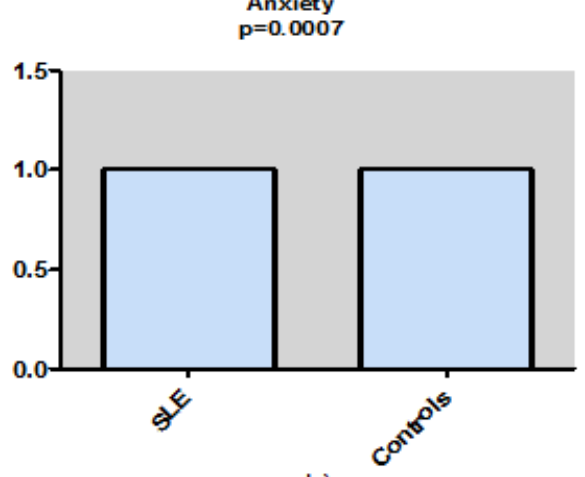

Evaluating the presence of anxiety, we found it present for 14 patients $(63.63 \%)$ and for 5 of the controls $(27.27 \%)$, $p<0.001$; depression was identified in 10 SLE patients $(45.45 \%)$, significant different compared to controls 
$(p<0.001)$ (fig. 2 a, b). The mean HAM-D score was $8.13+3.35$, most of the patients with a value associated to a mild depression; mean HAM-A score was $11.18+6.09,8$ patients with a mild level of anxiety and 5 with a moderate one (fig. $3 a, b)$.
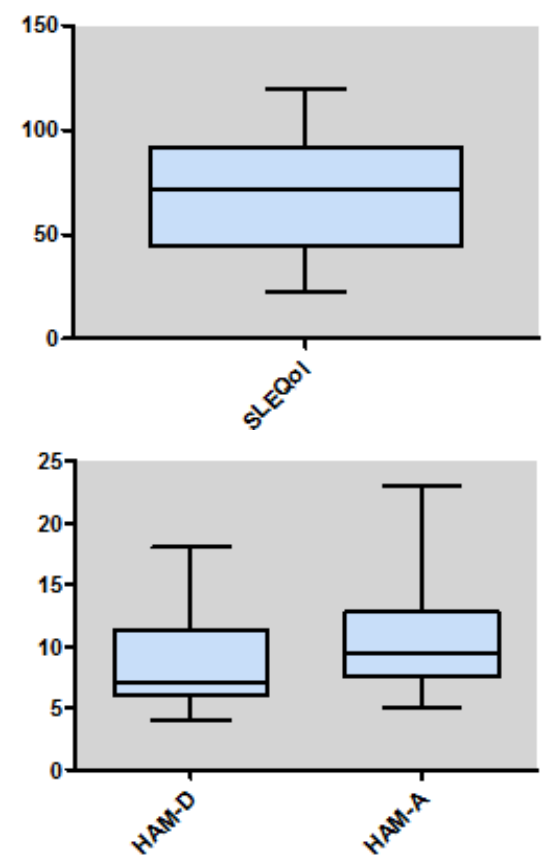

Fig. 3a. Mean HAM-A and HAM-D in SLE cohort; b) Mean SLEQol

Assessing quality of life, using SF 36 form, we obtained statistically significant differences between SLE patients and control group, mostly regarding physical functioning $(60.21+12.31 / 77.21+13.02 \% ; p=0.01)$, emotional wellbeing $(67.41+26.71 / 83.80+12.21, p=0.002)$ and role limitations due to emotional problems $(63.86+34.26 /$ $83.80+34.92 \% ; p=0.002)$. The results are presented in table 2.

Using SLEQol, we obtained a mean score of 71.14+30.68, with limits between 50 and 200 (fig. 3b).

The presence of depression negatively correlated to SF36 scores, regarding emotional well-being $(r=-0.601$, $p=0.003)$, physical functioning $(r=-0.497, p=0.018)$ and role limitation due to emotional problems $(r=-0.412$, $p=0.015)$; similar observations were made for the presence of anxiety: $r=-0.489, p=0.02$ for physical functioning, $r=-$ $.0477, p=0.024$ for emotional well-being and $r=-0.644$, $p=0.001$ for role limitation due to emotional problems. SLEQ ol scores moderately correlated both to the presence of anxiety and depression ( $r=-0.682 ; p<0.0001 / r=-0.518$; $p=0.013$ ).

We found a moderately positive correlation between SLEQol and HAM-D score $(r=0.536 ; p=0.029)$, as for SLEQol and HAM-A ( $r=0.551, p=0.017)$; for cognitive dysfunction we established as well a moderately positive correlation ( $r=0.575, p=0.041$ ) (table 3).

When evaluating the disease activity in relation to cognitive dysfunction, anxiety and depression, we found a positive correlation between SLEDAl, MocA, HAM-A and HAM-D (table 3).

SLE is the prototype of connective tissue diseases that can present the complete spectrum of neurologic and psychiatric alterations, cognitive dysfunction, depression and anxiety being more prevalent compared to general population, with an inputon patients' prognosis and quality of life $[1,2,16-19]$.

Our study found a prevalence of cognitive dysfunction of over $50 \%$, most of the patients with a mild degree, frequently involving orientation and attention. The reported percentage varies between $15-80 \%$ in different studies, depends on the method of evaluation, heterogeneity of the patients and is more frequent compared to other autoimmune rheumatologic conditions. Several reports, thatalso used MoCA scale, reported increased percentages, as the report published by Butt et al [33] or El-Shafei et al [34]. Lower percentages, under 10, were published by other authors [35, 36]. A recent metanalysis, published in 2018, that included 78 reports and over 2400 patients, concluded that cognitive dysfunction prevalence was higher compared to healthy subjects or rheumatoid arthritis [37].

The observation of a positive correlation between disease activity and cognitive dysfunction found in our cohort, was also reported in the Lupus Outcomes Study [38], in the study published by Conti et al [39] or Doman et al [40], whereas other investigations didn't have similar results [41, 42].

Similar to Calderon etal in 2017 [18], our results showed an impact of cognitive dysfunction on our patients' quality of life; in a similar manner, a recent study that included 98 NPSLE patients concluded that quality of life is reduced both in physical and mental domains, especially due to emotional problems [17], as well as the results of Hanlyet al [43].

Depression and anxiety are commonly diagnosed between SLE patients and the reported prevalence is variable between studies due to different methodology, screening tools and patient selection. Our cohort analysis showed the presence of depression and anxiety in a percentage significantly different compared to health individuals. Consistent to our data, a recent meta-analysis, concerning prevalence levels of depression and anxiety in adult SLE patients, published in 2017, that included 59 studies, reported a prevalence of depression between $2 \%$ and $91.7 \%$ and of anxiety between $4 \%$ and $84 \%$ [44], significantly higher compared to general population or other connective tissue diseases [45-51].

\begin{tabular}{|l|l|l|l|}
\hline & SLE (mean SD & Controls & $p$ \\
\hline Physical functioning & $60.21 \pm 12.31$ & $77.21 \pm 13.02$ & 0.01 \\
\hline General health & $61.36 \pm 16.77$ & $56.94 \pm 16.73$ & 0.287 \\
\hline Energy/fatigue & $83.18 \pm 7.32$ & $87.11 \pm 6.11$ & 0.06 \\
\hline Pain & $84.93 \pm 7.95$ & $87.44 \pm 8.07$ & 0.342 \\
\hline Social functioning lo to & $76.93 \pm 9.71$ & $87.11 \pm 8.27$ & 0.461 \\
\hline $\begin{array}{l}\text { Role limitation due } \\
\text { physical health }\end{array}$ & $87.06 \pm 8.15$ & 0.445 \\
\hline $\begin{array}{l}\text { Role limitation due to } \\
\text { emotional problems }\end{array}$ & $63.86 \pm 34.26$ & $83.80 \pm 34.92$ & 0.002 \\
\hline Emotional well-being & $67.41 \pm 26.71$ & $83.80 \pm 12.21$ & 0.002 \\
\hline
\end{tabular}

\begin{tabular}{|l|l|l|l|l|l|l|}
\hline \multirow{2}{*}{} & \multicolumn{2}{|c|}{ HAM-D } & \multicolumn{2}{c|}{ HAM-A } & \multicolumn{2}{c|}{ MoCA } \\
\cline { 2 - 7 } & $\mathrm{r}$ & $\mathrm{p}$ & $\mathrm{r}$ & $\mathrm{p}$ & $\mathrm{r}$ & $\mathrm{p}$ \\
\hline SLEDAI & 0.411 & 0.032 & 0.481 & 0.043 & 0.481 & 0.043 \\
\hline SLEQ0l & 0.536 & 0.029 & 0.551 & 0.017 & 0.575 & 0.041 \\
\hline
\end{tabular}

Table 3

CORRELATIONS BETWEEN DISEASE ACTIVITY, LIFE QUALITY AND DEPRESSION, ANXIETY AND COGNITIVE DYSFUNCTION SCALE 
The relationship between disease activity, depression and anxiety constituted the aim of several studies, with inconsistentresults; in our cohort, we noticed a moderately positive correlation between these variables, in consistency to those previously published by Julian etal [52], Bachen et al. [53] or by Bai et al, in 2016 [54].

Emotional disturbances are proven to negatively impact quality of life and are associated with long term progression of the disease and were extensively studied; a recent report that included a group of 113 SLE patients, concluded that patients with anxiety and/or depression reported lower SF36 scores compared to that without psychological disorders [55]. In a similar manner, Mok et al concluded that depressive/anxiety symptoms were more common in SLE patents and associated with a low quality of life and work disability [56]. Lower scores on the SF-36 (for QOL) were found in both male and female SLE patients with depression and anxiety symptoms by Macedo et al, in a report published in 2016 [57]. It is notew orthy that, in agreement with these findings, we noticed that depression and anxiety are directly inter-related to life quality assessment scores.

\section{Conclusions}

These findings underline the necessity and benefit of a careful and periodical neuropsychiatric examination, in order to recognize the clinical patterns in early stages, apply the proper therapeutic measures, quantify the future damage and improve the outcome of these patients.

Despite the relatively low number of subjects included in the study, to the best of our knowledge is the first in our country that studies the prevalence of some of the most common neuropsychiatric manifestations in SLE patients and their possible inter-relation to disease activity and quality of life. Our results are in agreement with other recently published studies and suggest its extension, with multicenter contribution and larger SLE cohorts. Also, the future directions should establish a diagnostic algorithm, associated to immunologic and imagistic findings, in order to individualize each patient's monitoring and prevent future complications, along with improving their quality of life.

\section{References}

1.KASAMA, T., MAEOKA, A., OGURO, N. Clinical Features of Neuropsychiatric Syndromes in Systemic Lupus Erythematosus and Other Connective Tissue Diseases, Clin Med Insights Arthritis Musculoskelet Disord., 18, 2016, p. 1-8.

2.BERTSIAS, G. K., BOUMPAS, D. T. Pathogenesis, diagnosis and management of neuropsychiatric SLE manifestations. Nat. Rev. Rheumatol., 6, nr.6, 2010, p. 358-367.

3.J ELTSCH-DAVID, H. MULLER, S. Neuropsychiatric systemic lupus erythematosus: pathogenesis and biomarkers, Nat. Rev. Neurol., 10, nr.10, 2014, p. 579-596.

4.BARBULESCU, A.L., VREJU, A.F., BUGA, A.M., SANDU, R.E., CRIVEANU, C., TUDORASCU, D.R., GHEONEA, I.A., CIUREA, P.L., Vascular endothelial growth factor in systemic lupus erythematosus - correlations with disease activity and nailfold capillaroscopy changes, Rom J Morphol Embryol., 56, nr.3, 2015, p.1011-1016.

5.FIRULESCU, S.C., TUDORASCU, D.R., PARVANESCU, C.D., CHISALAU, A.B., BASTIAN, A.E., EFREM, I.C., BARBULESCU, A.L., FORTOFOIU, M.C., CRIVEANU, C., IONESCU, P., DINESCU, S.C., TUDORANCEA, A.D., CIUREA, P.L., VREJU, A.F., The role of skin and muscle biopsy in the diagnosis of main connective tissue diseases, Rom J Morphol Embryol., 59, nr.1, 2018, p.55-64.
6.SANDU, R.E., UZONI, A., COMAN, C., POPA-WAGNER, A., Cerebral ischemia in the aged. Limited anti-inflammatory efficacy of the indomethacin treatment. Rom J Morphol Embryol., 56, nr.3, 2015, p. 1111-1117.

7.SANDU, R.E., DUMBRAVA, D., SURUGIU, R., GLAVAN D.G., GRESITA A, PETCU EB., Cellular and Molecular Mechanisms Underlying NonPharmaceutical Ischemic Stroke Therapy in Aged Subjects, Int J Mol Sci., 19, nr.1, 2017, pii: E99. doi: 10.3390/ijms19010099.

8.SANDU, R.E., BUGA, A.M., UZONI, A., PETCU, E.B., POPA-WAGNER, $A$., Neuroinflammation and comorbidities are frequently ignored factors in CNS pathology, Neural Regen Res., 10, nr.9, 2015, p. 13491355.

9.ALBU, C.V., PADUREANU, V., BOLDEANU, M.V., BUMBEA, A.M., ENESCU, A.S., ALBULESCU, D.M., SILOSI C.A., ENESCU, A., Vascular neurocognitive disorders and the vascular risk factors, Journal of mind and medical sciences, 5, nr.1, 2018, p.7-15.

10.POPA-WAGNER, A., BUGA, A.M., TICA, A.A., ALBU, C.V., Perfusion deficits, inflammation and aging precipitate depressive behavior, Biogerontology., 15, nr. 5, 2014, p. 439-448.

11.CATALIN, B., CUPIDO, A., IANCÃU, M., ALBU, C.V., KIRCHHOFF, F., Microglia: first responders in the central nervous system, Rom J Morphol Embryol., 54, nr.3, 2013, p. 467-472.

12.BARBULESCU, A.L., CIUREA, P.L., MITRAN, C., CHISALAU, B.A., PARVANESCU, C.D., FIRULESCU, S.C., BALASOIU, M., BOLDEANU, M.V., POPOVICIU, H., VREJU, F.A., High frequency ultrasonography of the hand versus anti-RA33 evaluation in early rheumatoid arthritis - a pilot study, Med Ultrason, 19, nr.2, 2017, p. 166-171.

13.VREJU, F.A., CIUREA, M.E., POPA, D., POPA, F., PARVANESCU, C.D., CHISALAU, B.A., BARBULESCU, A.L., PARVANESCU, V., ROSU, A., CIUREA, P.L., Ultrasonography in the diagnosis and management of noninflammatory conditions of the hand and wrist, Med Ultrason, 18, nr.1, 2016, p. 90-95.

14.TAISESCU, C.I., BICIUSCA, V., SAS, L., CAMEN, G., SAS, T., ALBU, C., TAISESCU, 0 . Changes of Visual Evoked Potentials in Patients with Thyroid Dysfunction, Rev. Chim. (Bucharest), 10, no.3, 2019, p. 961968.

15.TOADER, L.E., ROSU, G.C., CATALIN, B., PIRICI, I., GILCEAVA, I.C., ALBU, V.C., ISTRATE-OFITERU, A.M., MURESANU, D.F., PIRICI, D. Cerebrolysin increases motor recovery and decreases inflammation in a mouse model of autoimmune encephalitis. Romanian journal of morphology and embryology, 59, nr.3, 2018, p.755-762.

16.HOCHBERG M. et al. Rheumatology 95th edition, 2011, p.12231338.

17.MONAHAN, R.C., BEAART-VAN DE VOORDE, L.J.) ., STEUPBEEKMAN, G.M., MAGRO-CHECA C., HUIZINGA, T.W.J ., HOEKMAN, J., KAPTEIN, A.A., Neuropsychiatric symptoms in systemic lupus erythematosus: impact on quality of life, Lupus, 26, nr.12, 2017, p. 1252-1259.

18.CALDERON, J., FLORES, P., AGUIRRE, J.M., VALDIVIA, G., PADILLA, O., BARRA, I., SCORIELS, L., HERRERA, S., GONZALEZ, A. MASSARDO, L., Impact of cognitive impairment, depression, disease activity, and disease damage on quality of life in women with systemic lupus erythematosus, Scand J Rheumatol., 46, nr.12, 2017, p. 273-280.

19.GU, M., CHENG, Q., WANG, X., YUAN, F., SAM, N.B., PAN, H., LI, B., YE, D., The impact of SLE on health-related quality of life assessed with SF-36: a systemic review and meta-analysis, Lupus, 2, nr.3, 2019, p. 371-382.

20.CIUREA, M.E., CIUREA, R.N., BARBULESCU, A.L., CHISALAU A.B., PARVANESCU, C.D., FIRULESCU, S.C., COVEI BANICIOIU, S., CIUREA, P.L., VREJU, A.F. Intramuscular hemangioma of the arm: ultrasonography and pathology features, Rom J Morph Embryol, 57, nr.2, 2016, p. 521-524. 
21.FILIPPOU, G., SCIRE, C.A., ADINOLFI, A., DAMJ ANOV, N.S., CARRARA, G., BRUYN, G.A.W., CAZENAVE, T., D'AGOSTINO, M.A., DELLE SEDIE, A., DI SABATINO, V., DIAZ CORTES, M.E., FILIPPUCCI. E., GANDJBAKHCH, F., GUTIERREZ, M., MACCARTER, D.K., MICU, M., MÖLLER PARERA, I., MOUTERDE, G., MORTADA, M.A., NAREDO, E., PINEDA, C., PORTA, F., REGINATO, A.M., SATULU, I., SCHMIDT, W.A., SERBAN, T., TERSLEV, L., VLAD, V., VREJU, F.A., ZUFFEREY, P., BOZIOS, P., TOSCANO, C., PICERNO, V., IAGNOCCO, A., Identification of calcium pyrophosphate deposition disease (CPPD) by ultrasound: reliability of the OMERACT definitions in an extended set of joints-an international multiobserver study by the OMERACT Calcium Pyrophosphate Deposition Disease Ultrasound Subtask Force, Ann Rheum Dis, 77, nr.8, 2018, p. 1195-1200.

22.ANCUTA, C., POMIRLEANU, C., IORDACHE, C., FATU, A.M., POPESCU, E., ANCUTA, E., MIHAILOV, C. Periodontal Disease and Lipid Profile in Systemic Sclerosis: an EUSTAR Cohort Experience. Rev.Chim.(Bucharest), 68, no. 4, 2017, p. 890-893.

23. SAVA, I. SAVA, A. APTE, E., MIHAILOV, C., DUMITRESCU, G., POEATÃ, I., SAVA, F., HABA, D. Intraventricular metastatic clear cell renal carcinoma. Rom J Morphol Embryol., 54, nr.2, 2013, p. 44750.

24.MUSTAFA, E.R., FIRULESCU, S.C., PARVANESCU, C.D., CHISALAU, B.A., TARTEA, G.C., EFREM, I.C., BARBULESCU, A.L., DINESCU, S.C., CIUREA, P.L., RADU, L, Triple valve endocarditis-a late diagnosis, Journal of Mind and Medical Sciences, 5, nr.1, 2018, p.141-144. 25.PETRI, M., ORBAI, A.M., ALARCON, G.S., GORDON, C., MERRILL, J.T., FORTIN, P.R., BRUCE, I.N., ISENBERG, D., WALLACE, D.J ., NIVED, O., STURFELT, G., RAMSEY-GOLDMAN, R., BAE, S.C., HANLY, J.G., SÁNCHEZ-GUERRERO, J., CLARKE, A., ARANOW, C., MANZI, S., UROWITZ, M., GLADMAN, D., KALUNIAN, K., COSTNER, M., WERTH, V.P., ZOMA, A., BERNATSKY, S., RUIZIRASTORZA, G., KHAMASHTA, M.A., JACOBSEN, S., BUYON, J.P., MADDISON, P., DOOLEY, M.A., VAN VOLLENHOVEN, R.F., GINZLER, E., STOLL, T., PESCHKEN, C., JORIZZO, J.L., CALLEN, J.P., LIM, S.S., FESSLER, B.J ., INANC, M., KAMEN, D.L., RAHMAN, A., STEINSSON, K., FRANKS, A.G.JR., SIGLER, L., HAMEED, S., FANG, H., PHAM, N., BREY, R., WEISMAN, M.H., MCGWIN, G. JR., MAGDER, L.S., Derivation and validation of the Systemic Lupus International Collaborating Clinics classification criteria for systemic lupus erythematosus. Arthritis Rheum., 64, nr.8, 2012, p. 2677-86

26.BOMBARDIER, C., GLADMAN, D.D., UROWITZ, M.B., CARON, D., CHANG, C.H., Derivation of the SLEDAl. A disease activity index for lupus patients. The Committee on Prognosis on Studies in SLE, Arthritis Rheum, 35, nr.6, 1992, p. 630-640.

27.MOSCA, M., BOMBARDIERI, S., Assessing remission in systemic lupus erythematosus, Clin Exp Rheumatol, 24, nr.6 (suppl43), 2006, S-99-S-104.

28.***WWW.MOCATEST.ORG

29. HAMILTON, M., A rating scale for depression, J ournal of Neurology, Neurosurgery, and Psychiatry, 23, 1960, p. 56-62.

30.HAMILTON, M., The assessment of anxiety states by rating. The British J ournal of Medical Psychology, 32, nr.1, 1959, p 50-55.

31.WARE, J.E. JR., SHERBOURNE, C.D., The MOS 36-item short-form health survey (SF-36). I. Conceptual framework and item selection, Med Care., 30, nr.6, 1992, p. 473-83.

32.YAZDANY, ., Health-related quality of life measurement in systemic lupus erythematosus: The LupusQoL, SLEQoL, and L-QoL, Arthritis Care Res (Hoboken)., 63, nr. 11, 2011, S413-S419.

33.BUTT, B.A., FARMAN, S., KHAN, S.E., SAEED, M.A., AHMAD, N.M., Cognitive dysfunction in patients with Systemic Lupus Erythematosus, Pak J Med Sci. 33, nr.1, 2017, p. 59-64.

34.EL-SHAFEY, A.M., ABD-EL-GELEEL, S.M., SOLIMAN, E.S., Cognitive impairment in non-neuropsychiatric systemic lupus erythematosus, Egypt Rheum., 34, 2012, p. 67-73.
35. SANNA, G., BERTOLACCINI, M.L., CUADRADO, M.J ., LAING, H., KHAMASHTA, M.A., Mathieu A, Hughes GR., Neuropsychiatric manifestations in systemic lupus erythematosus: prevalence and association with antiphospholipid antibodies, J Rheumatol., 30, nr.5, 2003, p. 985-992.

36.HANLY, J.G., FISK, J.D., MCCURDY, G., FOUGERE, L., DOUGLAS, J.A., Neuropsychiatric syndromes in patients with systemic lupus erythematosus and rheumatoid arthritis, J Rheumatol., 32, nr.8, 2005, p.1459-1466.

37.RAYES, H.A., TANI, C., KWAN, A., MARZOUK, S., COLOSIMO, K., MEDINA-ROSAS, J., MUSTAFA, A., SU, J., LAMBIRIS, P., MOSCA, M., TOUMA, Z., What is the prevalence of cognitive impairment in lupus and which instruments are used to measure it? A systematic review and meta-analysis, Semin Arthritis Rheum., 48, nr.2, 2018, p. 240-255.

38.MURRAY, S.G., YAZDANY, J., KAISER, R., CRISWELL, L.A., TRUPIN, L., YELIN, E.H., KATZ, P.P., JULIAN LJ ., Cardiovascular disease and cognitive dysfunction in systemic lupus erythematosus, Arthritis Care Res, 64, nr.9, 2012, p. 1328-33.

39.CONTI, F., ALESSANDRI, C., PERRICONE, C., SCRIVO, R., REZAI, S., CECCARELLI, F., SPINELLI , F.R., ORTONA, E., MARIANETTI, M., MINA, C., VALESINI, G., Neurocognitive dysfunction in systemic lupus erythematosus: association with antiphospholipid antibodies, disease activity and chronic damage, PLoS One, 7, nr.3, 2012, e33824. doi: 10.1371/journal.pone.0033824.

40.DORMAN, G., MICELLI, M., COSENTINO, V., OTTONE, L., NUÑEZ, M.R., MANGONE, C., REY, R.C., KERZBERG, E., GENOVESE, O., Cognitive dysfunction in systemic lupus erythematosus in relation to disease activity and damage, Medicina (B Aires)., 77, nr. 4, 2017, p. 257-260.

41.TOMIETTO, P., ANNESE, V., D’AGOSTINI, S., VENTURINI, P., LA TORRE, G., DE VITA, S., FERRACCIOLI, G.F., General and specific factors associated with severity of cognitive impairment in systemic lupus erythematosus, Arthritis Rheum., 57, nr.8, 2007, p. 1461-72. 42.LAPTEVA, L., NOWAK, M., YARBORO, C.H., TAKADA, K., ROEBUCKSPENCER, T., WEICKERT, T., BLEIBERG, J., ROSENSTEIN, D., PAO, M., PATRONAS, N., STEELE, S., MANZANO, M., VAN DER VEEN, J.W., LIPSKY, P.E., MARENCO, S., WESLEY, R., VOLPE, B., DIAMOND, B., ILLEI, G.G., Anti-N-methyl-D-aspartate receptor antibodies, cognitive dysfunction, and depression in systemic lupus erythematosus, Arthritis Rheum., 54, nr.8, 2006, p. 2505-14.

43.HANLY, J.G., UROWITZ, M.B., SU, L., BAE, S.C., GORDON, C., WALLACE, D.J ., CLARKE, A., BERNATSKY, S., ISENBERG, D., RAHMAN, A., ALARCÓN, G.S., GLADMAN, D.D., FORTIN, P.R., SANCHEZGUERRERO, J., ROMERO-DIAZ, J., MERRILL, J.T., GINZLER, E., BRUCE, I.N., STEINSSON, K., KHAMASHTA, M., PETRI, M., MANZI, S., DOOLEY, M.A., RAMSEY-GOLDMAN, R., VAN VOLLENHOVEN, R., NIVED, O., STURFELT, G., ARANOW, C., KALUNIAN, K., RAMOS-CASALS, M., ZOMA, A., DOUGLAS, J., THOMPSON, K., FAREWELL, V., Systemic Lupus International Collaborating Clinics (SLICC). Prospective analysis of neuropsychiatric events in an international disease inception cohort of patients with systemic lupus erythematosus, Ann Rheum Dis., 69, nr.3, 2010, p. 529-35.

44.ZHANG, L., FU, T., YIN, T., QUIXIANG, Z., SHEN, B., Prevalence of depression and anxiety in systemic lupus erythematosus: a systematic review and meta-analysis, BMC Psychiatry, 17, nr.1, 2017, Feb 14; doi: 10.1186/s12888-017-1234-1.

45.GRECO, C.M., KAO, A.H., SATTAR, A., DANCHENKO, N., MAKSIMOWICZ-MCKINNON, K.M., EDMUNDOWICZ, D., SUTTONTYRRELL, K., TRACY, R.P., KULLER, L.H., MANZI, S., Association between depression and coronary artery calcification in women with systemic lupus erythematosus, Rheumatology (Oxford), 48, nr.5, p. 576-81.

46.SHEN, B., TAN, W., FENG, G., HE, Y., LIU, J., CHEN ,W., HUANG, $X$., $D A, Z$., XU, X.. LIU, H., GU, Z., The correlations of disease activity, socioeconomic status, quality of life, and depression/anxiety in Chinese patients with systemic lupus erythematosus, Clin Dev Immunol., 2013, 270878. doi: 10.1155/2013/270878. 
47.ZHANG, L., XIA, Y., ZHANG, Q., FU, T., YIN, R., GUO G, LI, L., GU, $Z$., The correlations of socioeconomic status, disease activity, quality of life, and depression/anxiety in Chinese patients with rheumatoid arthritis, Psychol Health Med., 22, nr.1, 2017, p. 28-36.

48.WESTHOFF, G., DORNER, T., ZINK, A., Fatigue and depression predict physician visits and work disability in women with primary Sjogren's syndrome: results from a cohort study, Rheumatology (Oxford), 51, nr.2, 2012, p. 262-9.

49.MAK, A., TANG, C.S., CHAN, M.F., CHEAK, A.A., HO, R.C., Damage accrual, cumulative glucocorticoid dose and depression predict anxiety in patients with systemic lupus erythematosus, Clin Rheumatol., 30, nr.6, 2011, p. 795-803.

50.TAY, S.H., CHEUNG, P.P., MAK, A., Active disease is independently associated with more severe anxiety rather than depressive symptoms in patients with systemic lupus erythematosus, Lupus, 24, nr. 13, 2015, p.1392-9.

51.STUBBS, B., ALUKO, Y., MYINT, P.K., SMITH, T.O., Prevalence of depressive symptoms and anxiety in osteoarthritis: a systematic review and meta-analysis, Age Ageing, 45, nr.2, 2016, p. 228-35.

52.J ULIAN, L.J., TONNER, C., YELIN, E,. YAZDANY, J., TRUPIN L, CRISWELL, L.A., KATZ, P.P., Cardiovascular and disease-related predictors of depression in systemic lupus erythematosus, Arthirtis Care Res, 63, nr.4, 2011, 542-9.
53.BACHEN, E. A., CHESNEY, M. A., CRISWELL, L. A., Prevalence of mood and anxiety disorders in women with systemic lupus erythematosus, Arthritis Care and Research, 61, nr.6, 2009, p. 822829.

54.BAI, R., LIU, S., ZHAO, Y., CHENG, Y., LI, S., LAI, A., XIE, Z., XU, $X ., L U, Z ., X U$, J., Depressive and Anxiety Disorders in Systemic Lupus Erythematosus Patients without Major Neuropsychiatric Manifestations, J Immunol Res., 2016, 2829018. Epub 2016 Sep 26. 55.YILMAZ-ONER， S., ONER， C., DOGUKAN, F.M., MOSES, T.F., DEMIR, K., TEKAYEV, N., YILMAZ, N., TUGLULAR, S., DIRESKENELI, H., Anxiety and depression predict quality of life in Turkish patients with systemic lupus erythematosus, Clin Exp Rheumatol., 33, nr.3, 2015, p. 360-5.

56.MOK, C.C., CHAN, K.L., HO, L.Y., Association of depressive/anxiety symptoms with quality of life and work ability in patients with systemic lupus erythematosus, Clin Exp Rheumatol., 34, nr.3, 2016, p. 389-95. 57.MACeDO, E.A., APPENZELLER, S., COSTALLAT, L.T., Gender differences in systemic lupus erythematosus concerning anxiety, depression and quality of life, Lupus, 25, nr.12, 2016, p. 1315-27.

$\overline{\text { Manuscript received:29.11.2018 }}$ 